\title{
DISTRIBUSI FREKUENSI PULPITIS REVERSIBEL DAN PULPITIS IREVERSIBEL DI RSGM FKG MOESTOPO PADA TAHUN 2014-2016 (Berdasarkan Jenis Kelamin, Usia dan Lokasi Gigi)
}

\author{
Sari Dewiyani*, Esther Julita Palupi** \\ *Departemen Konservasi, Fakultas Kedokteran Gigi, Universitas Prof. Dr. Moestopo (B), Jakarta \\ **Fakultas Kedokteran Gigi, Universitas Prof. Dr. Moestopo (B), Jakarta \\ Korespondensi: Sari Dewiyani, sari.drg@gmail.com
}

\begin{abstract}
ABSTRAK
Latar belakang: pulpa adalah jaringan lunak yang berada di tengah gigi yang di kelilingi oleh email dan dentin yang merupakan jaringan yang membentuk dan menyokong gigi. Pulpitis adalah jaringan pulpa yang terinflamasi dapat disebabkan oleh karies, trauma atau restorasi. Klasifikasi penyakit pulpa diantaranya adalah pulpitis reversibel dan pulpitis ireversibel. Pulpitis reversibel apabila dibiarkan tidak terawat dapat berlanjut menjadi pulpitis ireversibel. Tujuan: mengetahui distribusi frekuensi pulpitis reversibel dan pulpitis irevesibel berdasarkan jenis kelamin, usia, dan lokasi gigi pasien. Metode: deskriptif retrospektif dengan melakukan pengambilan data sekunder pada kartu rekam medik pasien konservasi di RSGM FKG Moestopo (B) pada tahun 2014-2016 dengan teknik simple random sampling. Jumlah sampel penelitian yang diambil adalah 380 kartu rekam medik. Hasil: pulpitis reversibel dan ireversibel di RSGM FKG Moestopo (B) pada tahun 2014-2016 sebesar 1822 kasus. Penyakit pulpa yang banyak terjadi adalah pulpitis reversibel pada wanita usia 18-28 tahun dan lokasi gigi terkena pulpitis adalah gigi molar.
\end{abstract}

Kata kunci: pulpa gigi, pulpitis reversibel, pulpitis ireversibel

\begin{abstract}
Background: pulp is a soft tissue located in the middle of the tooth and is the network that forms, supports and internal parts of the dentin and the surrounding enamel. Pulpitis is an inflamed pulp tissue caused by caries, trauma or restorations. Classification of pulp diseases included reversible pulpitis and irreversible pulpitis. Reversible pulpitis if left untreated may progress to irreversible pulpitis. Purpose: this study used to know the frequency distribution of reversible pulpitis and irreversible pulpitis based on gender, age, and location of the teeth. Method: Descriptive retrospective with secondary data retrieval on conservation patient medical record card at RSGM FKG Moestopo(B) in 2014-2016 with simple random sampling technique. The number of samples taken is 380 medical record cards. Result: reversible and irreversible pulpitis at RSGM FKG Moestopo(B) in 2014-2016 amounted to 1822 cases. The most common pulp disease was reversible pulpitis in women aged 18-28 years and the location of teeth affected by pulpitis is a molar tooth.
\end{abstract}

Keywords: pulp tooth, reversible pulpitis, irreversible pulpitis

\section{LATAR BELAKANG}

$\mathrm{P}$ revalensi penyakit pulpa dan periapeks relatif tinggi di Indonesia. Daftar Tabulasi Dasar (DTD) tahun 2006 menyatakan bahwa penyakit pulpa dan periapeks menempati posisi ke-11 dari seluruh penyakit rawat jalan di Rumah Sakit Indonesia dengan jumlah 30,06\%. Bahkan pada tahun 2009 dan 2010, berdasarkan pola 10 penyakit terbesar pada pasien rawat jalan Rumah Sakit di Indonesia, penyakit pulpa dan periapeks mengalami peningkatan posisi yaitu dari posisi ke-9 menjadi posisi 8 dari seluruh penyakit dengan jumlah kasus tahun 2009 sebanyak 122.467 kasus dan tahun 2010 sebanyak 208.888 kasus. ${ }^{2,3}$

Penyakit pulpa awalnya terdiagnosis dengan keluhan gigi berlubang akibat karies gigi yang disebabkan bakteri atau fraktur gigi. Pasien seringkali datang ke dokter gigi setelah kelainan tersebut berlanjut. Keluhan gigi berlubang akibat karies maupun fraktur gigi yang tidak ditangani segera akan menyebabkan bakteri masuk ke dalam pulpa 
yang terbuka. Penyakit pulpa juga dapat disebabkan oleh trauma akibat benturan benda keras, panas yang berasal dari preparasi kavitas dan efek toksik dari bahan restorasi itu sendiri. ${ }^{4,5}$

Karies gigi dapat menyebabkan rasa sakit bila terkena makanan atau minuman dingin atau manis. Hal ini menjadi salah satu indikasi terjadinya pulpitis reversibel yang apabila dibiarkan tidak dirawat dapat berlanjut menjadi pulpitis ireversibel. Karies gigi yang dibiarkan saja hingga mencapai pulpa dapat menyebabkan perawatan yang lebih lama dan kompleks. ${ }^{4,5}$ Penyakit pulpa atau pulpitis atau inflamasi pulpa mempunyai gejala dan reaksi yang berbeda-beda untuk setiap inividu. Reaksi yang dihasilkan tidak saja tergantung pada derajat iritasi pulpa, tetapi juga pada susunan individual pulpa dan resistensi jaringan pulpa terhadap inflamasi. ${ }^{5}$

Klasifikasi penyakit pulpa dibagi menjadi tiga bagian besar menurut Ingle, yaitu reversible pulpitis, irreversible pulpitis (accute irreversible, chronic irreversible hiperplastic pulpitis), dan nekrosis pulpa. ${ }^{6}$

Pulpitis reversibel adalah penyakit pulpa yang dapat berubah menjadi pulpa normal kembali apabila stimulus iritan dihilangkan, sedangkan pada pulpitis irevesibel kecil kemungkinan menjadi pulpa normal kembali walaupun stimulus iritan sudah dihilangkan kecuali dengan perawatan endodontik. ${ }^{14}$

Penanganan perawatan pulpitis reversibel dan pulpitis ireversibel dapat dilakukan di RSGM FKG Moestopo (B). RSGM FKG Moestopo (Rumah Sakit Gigi dan Mulut) adalah rumah sakit khusus yang digunakan untuk pendidikan dan pelayanan kesehatan gigi milik Fakultas Kedokteran Gigi Universitas Prof.Dr.Moestopo (Beragama). Pasien yang datang ke RSGM FKG Moestopo (B) untuk mendapatkan penanganan perawatan bervariasi dalam usia, jenis kelamin, gigi yang terkena penyakit pulpa dan jenis penyakit pulpa. Namun sampai saat ini belum diketahui data-data pasien yang datang ke klinik konservasi gigi berdasarkan usia, jenis kelamin dan lokasi gigi untuk mendapatkan perawatan.

\section{METODE PENELITIAN}

Jenis penelitian ini merupakan penelitian deskriptifdengan menggunakan pendekatan kroseksional. Pengambilan sampel dilakukan dengan menggunakan metode simple random sampling. Sampel adalah seluruh kartu rekam medik pasien yang melakukan tindakan perawatan saluran akar di RSGM FKG UPDM (B) pada tahun 2014-2016. Subjek penelitian ini berupa data sekunder yang didapat dari daftar kartu status pasien.

Kriteria inklusi dalam penelitian ini yaitu pengambilan seluruh data status rekam medik pasien di bagian klinik konservasi RSGM FKG UPDM (B) pada tahun 2014-2016 yang memiliki informasi tentang keluhan penyakit pulpa yang berupa pulpitis reversibel dan pulpitis ireversibel.
Sampel pada penelitian ini adalah total sampling yaitu seluruh rekam medik pasien yang dilakukan penambalan gigi di bagian klinik konservasi RSGM FKG UPDM (B) pada tahun 2014-2016.

Jenis penelitian ini merupakan penelitian deskriptif, maka sampel dihitung dengan rumus Slovin ${ }^{13}$ dengan jumlah sampel 380 kartu rekam medis.

\section{HASIL PENELITIAN}

Hasil penelitian dari pengolahan data dapat dilihat pada tabel berikut.

Tabel 1. Distribusi Frekuensi Jenis Kelamin terhadap Usia

\begin{tabular}{cccccccc}
\hline & \multicolumn{6}{c}{ Usia } \\
\cline { 2 - 6 } $\begin{array}{c}\text { Jenis } \\
\text { Kelamin }\end{array}$ & $\begin{array}{c}<\mathbf{1 7} \\
\text { Tahun }\end{array}$ & $\begin{array}{c}\mathbf{1 8 - 2 8} \\
\text { Tahun }\end{array}$ & $\begin{array}{c}\mathbf{2 9 - 3 8} \\
\text { Tahun }\end{array}$ & $\begin{array}{c}\mathbf{3 9 - 4 8} \\
\text { Tahun }\end{array}$ & $\begin{array}{c}\mathbf{4 9 - 5 8} \\
\text { Tahun }\end{array}$ & $\begin{array}{c}>\mathbf{5 8} \\
\text { Tahun }\end{array}$ & Total \\
\hline Pria & 1 & 72 & 18 & 18 & 13 & 4 & 126 \\
Wanita & 1 & 103 & 51 & 65 & 22 & 12 & 254 \\
Total & 2 & 175 & 69 & 83 & 35 & 16 & 380 \\
\hline
\end{tabular}

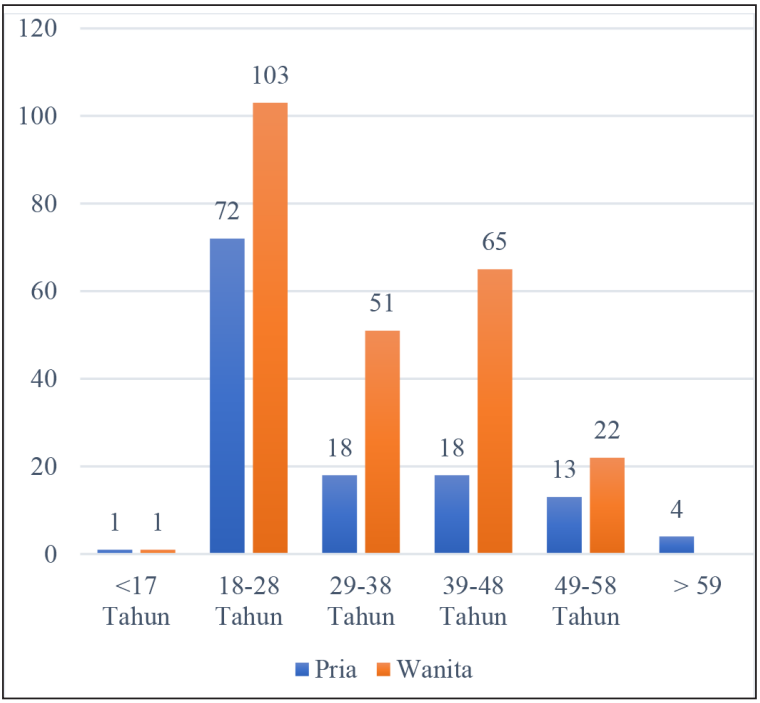

Grafik 1. Distribusi Frekuensi berdasarkan Jenis Kelamin Terhadap Usia

Berdasarkan tabel 1 terlihat tabulasi silang karakteristik pasien yang berkunjung ke klinik berdasar pada jenis kelamin dan usia. Terlihat bahwa terdapat satu pasien pria dan wanita berusia di bawah 18 tahun yang berkunjung ke klinik dalam 3 tahun terakhir, pasien yang berusia 18-28 tahun pada pria dan wanita masing-masing berjumlah 72 dan 103 pasien, pada usia 29-38 tahun pasien yang datang berjumlah 18 orang pria serta 51 orang wanita. Rentang usia 39-48 tahun terdapat 18 pasien pria, 65 pasien wanita. Kategori usia keempat yaitu 49-58 tahun jumlah pasien pria yang datang berjumlah 13 orang dan 22 orang untuk pasien wanita. Sementara itu untuk kategori usia terakhir yaitu 
lebih dari 58 tahun ada 4 pasien pria dan 12 pasien wanita. Total pasien berkunjung pada tahun 2014-2016 baik di pria maupun wanita usia 18-28 tahun merupakan kategori dengan jumlah pasien terbanyak, sedangkan untuk kategori lebih dari 58 tahun memiliki pasien paling sedikit. Secara keseluruhan kunjungan pasien wanita dua kali lebih banyak dari pria tahun 2014-2016.

Tabel 2: Distribusi Frekuensi Pulpitis Reversibel dan Pulpitis Ireversibel Berdasarkan Jenis Kelamin

\begin{tabular}{ccccc}
\hline \multirow{2}{*}{$\begin{array}{c}\text { Jenis } \\
\text { Kelamin }\end{array}$} & \multicolumn{2}{c}{ Pulpitis Ireversibel } & $\begin{array}{c}\text { Pulpitis } \\
\text { Reversibel }\end{array}$ & Total \\
\cline { 2 - 4 } Primptomatik & 44 & imptomatik & \\
Wanita & 60 & 16 & 475 & 535 \\
Total & 104 & 26 & 1201 & 1287 \\
\hline
\end{tabular}

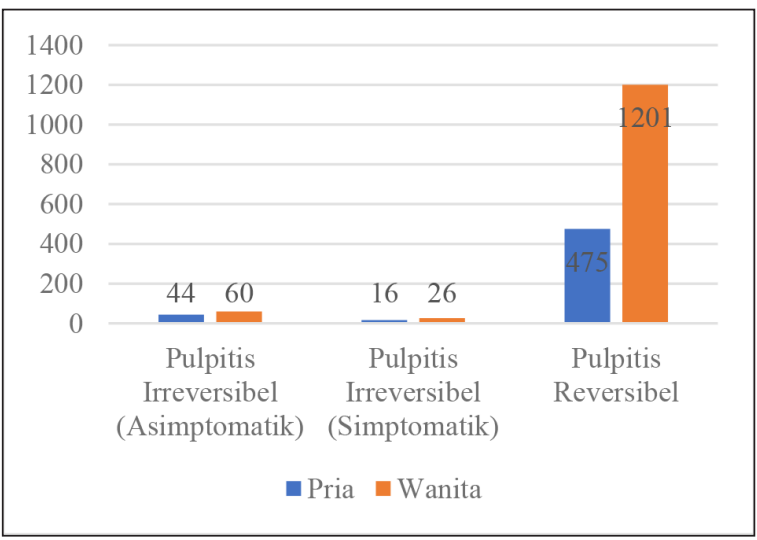

Grafik 2. Distribusi Frekuensi Pulpitis Reversibel dan Pulpitis Ireversibel Berdasarkan Jenis Kelamin

Pada tabel 2 dan grafik 2 dipaparkan bahwa antara jenis kelamin dan pulpiltis, terlihat bahwa pasien pria menderita pulpitis ireversibel simptomatik sebanyak 16 gigi sedangkan pasien wanita 26 gigi. Pasien pria dengan pulpitis ireversibel asimptomatik sebanyak 44 gigi dan 60 gigi pada pasien wanita sedangkan untuk pulpitis reversibel sebanyak 475 gigi pada pria dan 1201 gigi pada wanita. Secara umum dapat dilihat bahwa wanita penderita pulpitis ireversibel asimptomatik dan simptomatik maupun pulpitis reversibel lebih banyak jumlahnya dibandingkan pria.

Tabel 3. Distribusi Frekuensi Pulpitis Reversibel dan Pulpitis Ireversibel Berdasarkan Usia

\begin{tabular}{ccccccccc}
\hline & \multicolumn{6}{c}{ Usia (Tahun) } & \\
\cline { 3 - 7 } \multicolumn{2}{c}{ Pulpitis } & $<$ & $\mathbf{1 8}$ & $\mathbf{2 9}$ & $\mathbf{3 9}$ & $\mathbf{4 9}$ & $>$ & Total \\
& $\mathbf{1 7}$ & $\mathbf{- 2 8}$ & $\mathbf{- 3 8}$ & $\mathbf{- 4 8}$ & $\mathbf{- 5 8}$ & $\mathbf{5 8}$ & \\
\hline \multirow{2}{*}{ Ireversibel } & Asimptomatik & 0 & 49 & 22 & 27 & 3 & 2 & 103 \\
& Simptomatik & 0 & 18 & 7 & 13 & 3 & 2 & 43 \\
\cline { 3 - 7 } Reversibel & 12 & 739 & 332 & 367 & 158 & 68 & 1676 \\
\multicolumn{2}{c}{ TOTAL } & 12 & 806 & 361 & 407 & 164 & 72 & 1822 \\
\hline
\end{tabular}

Pada tabel 3 dan grafik 3 pasien yang berkunjung ke klinik berdasar pada kasus pulpitis dan usia terlihat bahwa terdapat 12 gigi reversibel pada usia di bawah 18 tahun yang berkunjung ke klinik dalam 3 tahun terakhir. Pasien yang berusia 18-28 tahun terdapat 18 gigi ireversibel simptomatik, 49 gigi ireversibel asimptomatik dan 739 gigi reversibel.

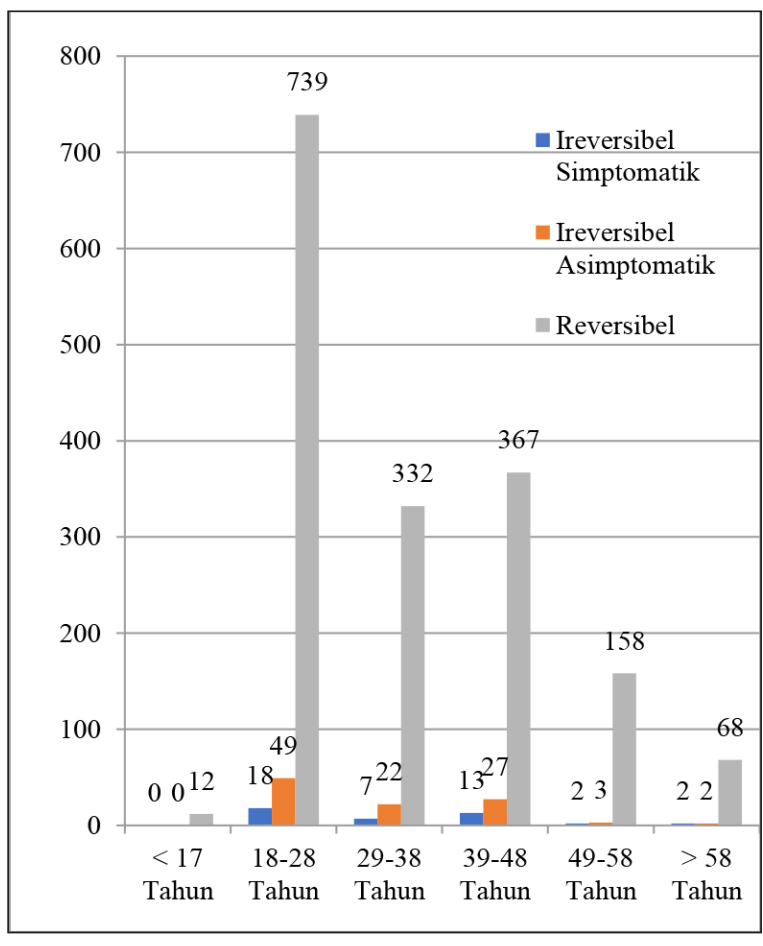

Grafik 3. Distribusi Frekuensi Pulpitis Reversibel dan Pulpitis Ireversibel Berdasarkan Usia

Pada usia 29-38 tahun pasien yang datang terdapat 7 gigi ireversibel simptomatik, 22 gigi ireversibel asimptomatik dan 332 gigi reversibel. Rentang usia 39-48 tahun terdapat 13 gigi ireversibel simptomatik, 27 gigi ireversibel asimptomatik dan 367 gigi reversibel. Kategori usia keempat yaitu 4958 tahun terdapat 3 gigi ireversibel asimptomatik, 3 ireversibel simptomatik dan 158 gigi reversibel. Sementara itu untuk kategori usia terakhir yaitu lebih dari 58 tahun terdapat 2 gigi ireversibel asimptomatik, 2 reversibel simptomatik dan 68 gigi reversibel.

Tabulasi dari total letak gigi yang mengalami pulpitis reversibel dan ireversibel dari tahun 20142016 terlihat pada tabel 4 . 
Tabel 4. Distribusi Frekuensi Pulpitis Reversibel dan Pulpitis Ireversibel Berdasarkan Lokasi Gigi

\begin{tabular}{|c|c|c|c|c|c|}
\hline \multirow{2}{*}{ Unsur } & \multirow{2}{*}{ Gigi } & \multirow{2}{*}{$\begin{array}{c}\begin{array}{c}\text { Pulpitis } \\
\text { Reversibel }\end{array} \\
\mathrm{N}(\%)\end{array}$} & \multicolumn{2}{|c|}{ Pulpitis Ireversibel } & \multirow{2}{*}{$\begin{array}{l}\text { Total } \\
N(\%)\end{array}$} \\
\hline & & & $\begin{array}{c}\text { Asimptomatik } \\
\mathbf{N}(\%)\end{array}$ & $\begin{array}{c}\text { Simptomatik } \\
\text { N(\%) }\end{array}$ & \\
\hline \multirow{6}{*}{$\begin{array}{l}\text { Regio Kanan } \\
\text { Atas }\end{array}$} & Gigi 11 & $89(89)$ & $2(2)$ & $9(9)$ & $100(100)$ \\
\hline & Gigi 12 & $58(96.67)$ & $0(0)$ & $2(3.34)$ & $60(100)$ \\
\hline & Gigi 13 & $33(97.07)$ & $1(2.95)$ & $0(0)$ & $34(100)$ \\
\hline & Gigi 14 & $51(92.74)$ & $1(1.82)$ & $3(5.46)$ & $55(100)$ \\
\hline & Gigi 15 & $47(100)$ & $0(0)$ & $0(0)$ & $47(100)$ \\
\hline & Gigi 16 & $92(88.47)$ & $5(4.81)$ & $7(6.74)$ & $104(100)$ \\
\hline \multirow{10}{*}{$\begin{array}{c}\text { Regio Kiri } \\
\text { Atas }\end{array}$} & Gigi 17 & $76(95)$ & $2(2.5)$ & $2(2.5)$ & $80(100)$ \\
\hline & Gigi 18 & $45(93.76)$ & $1(2.09)$ & $2(4.17)$ & $48(100)$ \\
\hline & Gigi 21 & $84(86.61)$ & $0(0)$ & $13(13.41)$ & $97(100)$ \\
\hline & Gigi 22 & $56(93.34)$ & $0(0)$ & $4(6.67)$ & $60(100)$ \\
\hline & Gigi 23 & $36(97.31)$ & $1(2.71)$ & $0(0)$ & $37(100)$ \\
\hline & Gigi 24 & $67(92.17)$ & $0(0)$ & $4(7.85)$ & $51(100)$ \\
\hline & Gigi 25 & $56(98.26)$ & $0(0)$ & $1(1.76)$ & $57(100)$ \\
\hline & Gigi 26 & $97(93.27)$ & $2(1.93)$ & $5(4.81)$ & $104(100)$ \\
\hline & Gigi 27 & 97(98.99) & $1(1.03)$ & $0(0)$ & $98(100)$ \\
\hline & Gigi 28 & $58(95.09)$ & $0(0)$ & $3(4.92)$ & $61(100)$ \\
\hline \multirow{6}{*}{$\begin{array}{l}\text { Regio Kiri } \\
\text { Bawah }\end{array}$} & Gigi 31 & $8(100)$ & $0(0)$ & $0(0)$ & $8(100)$ \\
\hline & Gigi 32 & $8(88.9)$ & $0(0)$ & $1(11.12)$ & $9(100)$ \\
\hline & Gigi 33 & $11(91.67)$ & $0(0)$ & $1(8.34)$ & $12(100)$ \\
\hline & Gigi 34 & $30(93.76)$ & $1(3.13)$ & $1(3.13)$ & $32(100)$ \\
\hline & Gigi 35 & $37(92.5)$ & $1(2.5)$ & $2(5)$ & $40(100)$ \\
\hline & Gigi 36 & $83(83.85)$ & $3(3.04)$ & $13(13.14)$ & $99(100)$ \\
\hline \multirow{10}{*}{$\begin{array}{l}\text { Regio Kanan } \\
\text { Bawah }\end{array}$} & Gigi 37 & $117(94.36)$ & $3(2.42)$ & $4(3.23)$ & $124(100)$ \\
\hline & Gigi 38 & $56(94.93)$ & $0(0)$ & $3(5.09)$ & $59(100)$ \\
\hline & Gigi 41 & $5(100)$ & $0(0)$ & $0(0)$ & $5(100)$ \\
\hline & Gigi 42 & $13(100)$ & $0(0)$ & $0(0)$ & $13(100)$ \\
\hline & Gigi 43 & $14(93.34)$ & $0(0)$ & $1(6.67)$ & $15(100)$ \\
\hline & Gigi 44 & $28(90.34)$ & $1(3.23)$ & $2(6.46)$ & $31(100)$ \\
\hline & Gigi 45 & $38(100)$ & $0(0)$ & $0(0)$ & $38(100)$ \\
\hline & Gigi 46 & $72(75.8)$ & $5(5.27)$ & $18(18.95)$ & $95(100)$ \\
\hline & Gigi 47 & $85(87.64)$ & $2(2.07)$ & $10(10.31)$ & $97(100)$ \\
\hline & Gigi 48 & $49(94.24)$ & $0(0)$ & $3(5.77)$ & $52(100)$ \\
\hline
\end{tabular}

Beberapa letak gigi pasien yaitu gigi 11, gigi 16, gigi 26 dan gigi 37 (ditandai warna kuning) merupakan gigi yang paling banyak mengalami pulpitis reversibel dan ireversibel.

Keseluruhan pasien yang datang dari tahun 2014 sampai 2016 letak gigi 31, gigi 32 dan gigi 33 serta 43 (ditandai warna biru) merupakan gigi yang paling sedikit mengalami pulpitis reversibel dan ireversibel.

Perbandingan sebaran kedatangan pasien berdasarkan usia per setiap tahunnya terlihat pada grafik 4. Pasien berusia dibawah 18 tahun yang datang ke klinik hanya ada pada tahun 2015, pada rentang usia pasien 18-28 tahun merupakan yang paling banyak datang di setiap tahunnya. Kemudian rentang usia pasien 39-48 tahun, dan semakin mengecil frekuensi kunjungan pasien di rentang usia lebih dari 58 tahun setiap tahunnya. Ini menandakan usia 18-28 tahun merupakan usia yang paling peduli terhadap kesehatan gigi. Secara umum terlihat bahwa setiap tahunnya pada setiap rentang usia kedatangan frekuensi pasien cukup berimbang.

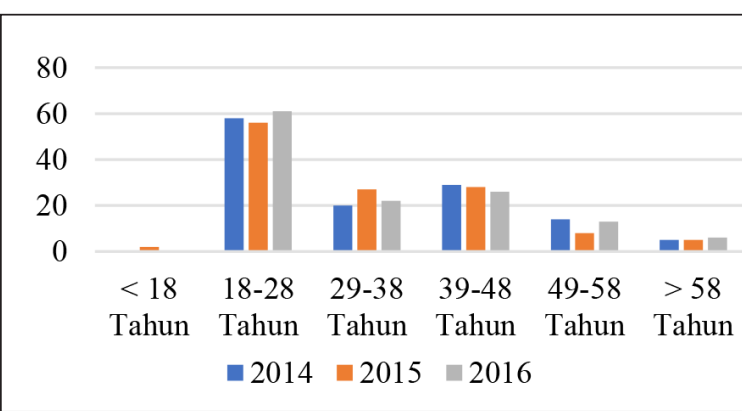

Grafik 4. Distribusi Kedatangan Pasien Penderita Pulpitis Berdasarkan Tahun 2014-2016

\section{PEMBAHASAN}

Pada tabel 1 memaparkan dari tahun 2014 2016 pasien yang datang ke RSGM FKG Moestopo (B) didominasi oleh pasien wanita untuk semua sebaran usia antara 18 tahun sampai lebih dari 58 tahun. Hal tersebut dimungkinkan karena wanita lebih memperhatikan kesehatan dan estetik termasuk di antaranya kesehatan gigi geliginya. Shaffer dkk menyatakan perbedaan jenis kelamin pada studi yang dilakukan menunjukkan bahwa wanita dewasa dan remaja wanita lebih beresiko terkena karies gigi dibandingkan pria. ${ }^{16,20}$

Proporsi usia antara 18 - 28 tahun juga dipaparkan menempati urutan teratas jumlah pasien yang datang. Berdasarkan kelompok usia, pasien yang paling banyak datang dari kelompok usia produktif. Hal ini diperkirakan pada kurun usia tersebut kerusakan gigi yang timbul sudah menjadi masalah yang mengganggu kesehatan gigi pasien, terutama saat menggunakan gigi geliginya.

Wanita pada umumnya lebih banyak menderita pulpitis reversibel maupun pulpitis ireversibel hal itu dapat dilihat pada tabel 2 dan grafik 2. Penelitian Shaffer dkk dan Lukacs dkk menunjukkan prevalensi penyakit gigi pada wanita tersebut dapat disebabkan oleh faktor-faktor seperti: 1) remaja wanita lebih dahulu mengalami erupsi gigi dari pada pria sehingga memungkinkan wanita lebih lama terpapar zat-zat yang bersifat oral kariogenik. 2) wanita lebih mudah berhubungan dengan makanan terutama pada saat proses pembuatannya sehingga memungkinkan wanita untuk mencicipi makanan tersebut. 3) pengaruh hormonal dan kehamilan. Faktor-faktor yang mendukung cepatnya penyakit pulpa pada ibu hamil karena $\mathrm{pH}$ saliva ibu hamil lebih asam jika dibandingkan dengan yang tidak hamil. Serangan asam pada plak merupakan awal terjadinya penyakirt pulpa. ${ }^{17,18,2}$ 
Pada tabel 3 dan grafik 2 memperlihatkan antara tahun 2014 - 2016 pasien yang datang ke RSGM FKG Moestopo (B) lebih banyak yang menderita pulpitis reversibel dibandingkan pulpitis ireversibel. Semua usia dapat mengalami pulpitis reversibel maupun ireversibel, sesuai grafik 2.

Awal penyakit pulpa dimulai dari pulpitis reversibel. Pulpitis reversibel dikarakteristikkan adanya hipersensitif terhadap suhu maupun stimulasi kimia yang tiba-tiba menghilang pada saat stimulus dihilangkan. ${ }^{19}$ Saat pasien makan dan minum dingin, pasien terasa nyeri sehingga pasien tersebut menjadi tidak nyaman.5 Ketidaknyamanan menyebabkan penderita pulpitis mengunjungi dokter gigi terdekat dengan harapan masih dapat sehat kembali. Penderita pulpitis ireversibel sering bermula juga dari latar belakang ekonomi dimana pasien pulpitis reversibel, sering menghindari klinik gigi karena lebih dahulu takut dengan biaya yang relatif mahal. Meskipun pulpitis ireversibel sering dihubungkan dengan sakit yang tiba-tiba ataupun berkepanjangan setelah dipicu sesuatu yang spesifik, namun terkadang juga tidak terlihat gejala pada penyakit ini. ${ }^{21}$ Keadaan tersebut membuat penderita pulpitis reversibel menganggap itu dapat mereka obati dengan obat-obatan analgesik. Kurangnya kesadaran itu yang akhirnya berkembang menjadi pulpitis ireversibel.

Terdapat pulpitis ireversibel untuk semua kategori usia pada tabel 3 dan grafik 2, tapi dengan jumlah yang tidak terlalu jauh.

Pada tabel 4 berdasarkan lokasi gigi terlihat bahwa gigi yang banyak mengalami pulpitis pada pasien yang datang ke RSGM FKG Moestopo (B) sepanjang tahun 2014-2016 adalah gigi insisif, molar 1 dan molar 2. Sedangkan gigi yang paling sedikit mengalami pulpitis adalah gigi anterior bawah.

Tabel tersebut di atas didukung oleh hasil penelitian Sagita M., dkk yang menyatakan bahwa elemen gigi yang paling banyak dilakukan Perawatan Saluran Akar adalah gigi molar 1 permanen kanan rahang bawah dan molar 1 permanen kiri rahang bawah sedangkan elemen gigi yang selama penelitiannnya tidak ditemukan dilakukan PSA adalah gigi kaninus permanen kanan rahang atas, kaninus kiri permanen rahang atas, kaninus kiri permanen rahang bawah, insisif sentral permanen kiri rahang bawah, insisif lateral permanen kiri rahang bawah, insisif sentral permanen kanan rahang bawah dan premolar 1 permanen kanan rahang bawah. ${ }^{22}$ Ahmed dkk menyatakan bahwa molar merupakan yang paling banyak dilakukan PSA, dan didukung hasil penelitian Oglah dkk yang menyatakan bahwa molar permanen rahang bawah merupakan gigi yang paling sering dilakukan PSA. ${ }^{23,24}$

Perawatan Saluran Akar (PSA) merupakan salah satu tindakan perawatan pada pasien penderita pulpitis ireversibel. Gigi molar 1 menurut data di atas adalah gigi geligi yang paling sering dilakukan perawatan PSA. Hal ini didukung dengan pernyataan bahwa gigi molar merupakan gigi yang beresiko mengalami karies, terutama fissure dan permukaan proksimal, dari aspek mesial molar kedua sampai aspek distal premolar pertama. Selain itu gigi molar 1 permanen merupakan gigi permanen pertama yang erupsi sehingga paling lama terpapar dengan etiologi karies. ${ }^{25,27}$

Gigi insisif juga dapat terkena pulpitis berdasarkan pada tabel 4. Hal ini didukung oleh penelitian Marza dan Ranj yang menyatakan bahwa insisif sentral dan premolar 1 permanen rahang atas yang paling banyak dilakukan PSA.

Pada grafik 3 menggambarkan perbandingan sebaran kedatangan pasien berdasarkan usia per setiap tahunnya. Pada rentang usia pasien 18-28 tahun merupakan yang paling banyak datang di setiap tahunnya kemudian disusul oleh rentang usia pasien 39-48 tahun, Pada usia 18 sampai 48 tahun merupakan usia produktif yang masih peduli dengan kesehatan dan penampilan. Terlihat juga dari gambaran setiap tahunnya pada setiap rentang usia. Berdasarkan gambaran di atas, yang harus juga berbenah adalah Rumah Sakit Gigi dan Mulut FKG Moestopo UPDM (B) sehingga tetap dapat menjaga kesadaran pasien untuk tetap semakin peduli dengan kesehatan dan estetika gigi.

\section{KESIMPULAN DAN SARAN}

Distribusi frekuensi pulpitis reversibel dan ireversibel di RSGM FKG Moestopo (B) pada tahun 2014 - 2016 pasien yang datang ke RSGM FKG MOESTOPO(B) terbanyak adalah pasien wanita dengan rentang usia antara 18 tahun sampai lebih dari 58 tahun, dan wanita pada umumnya lebih banyak menderita pulpitis reversibel maupun pulpitis ireversibel. Hal tersebut dimungkinkan karena wanita lebih memperhatikan kesehatan dan estetik termasuk di antaranya kesehatan gigi geliginya.

Berdasarkan lokasi gigi terlihat bahwa gigi yang banyak mengalami pulpitis pada pasien yang datang ke RSGM FKG Moestopo (B) sepanjang tahun 2014-2016 adalah gigi insisif, molar 1 dan molar 2 . Gigi molar merupakan gigi yang beresiko mengalami karies, selain itu gigi molar 1 permanen merupakan gigi permanen pertama yang erupsi sehingga paling lama terpapar dengan etiologi karies.

\section{DAFTAR PUSTAKA}

1. Riset Kesehatan Dasar. Badan Penelitian Pengembangan Kesehatan. Departemen Kesehatan Republik Indonesia. Jakarta: Laporan Nasional; 2013.

2. Departemen Kesehatan. Profil Kesehatan Indonesia Tahun 2009.Jakarta: Departemen Kesehatan Republik Indonesia;2010.

3. Departemen Kesehatan. Profil Kesehatan Indonesia Tahun 2010.Jakarta: Departemen Kesehatan Republik Indonesia; 2011. 
4. Walton R dan Torabinejas M. Prinsip dan Praktik Ilmu Endodonsia. Edisi ketiga. Terjemahan: Sumawinta N. Editor: Juwono L. Jakarta: EGC; 2008: 4-18.

5. Grossman L, Oliet S, Ilmu Endodontik Dalam Praktek;Terjemahan: Rafiah Abyono;edisi 11; Jakarta; EGC; 1995; 32-79.

6. Ingle JI, Bakland LK. Endodontics. 5th ed. ;B.C. Decker, Inc; Ontario; 2002:179-186.

7. Ingle J.I,Bakland L.K, Endodotics6; 6th; BC Decker; Ontario;2008: 37

8. Putri MH, Herijulianti E, Nurjannah N. Ilmu Pencegahan Penyakit Jaringan Keras dan Jaringan Pendukung Gigi. Jakarta: EGC; 2010: hal. 15,19,21-22.

9. http://intranet.tdmu.edu.ua/data/kafedra/internal/stomat ter/classes_stud/en/stomat/ptn/Propaedeutics $\% 20$ of $\% 20$ Therapeutic\%20dentistry/ 2\% 20year/10.\%20 Endodontics\%20\%20its\%20objectives\%20and\% 20goals.\%20.files/image010.jpg (diakses tanggal 10 Juni 2017).

10. Garg N.,Garg A.,Textbook of Preclinical Conservative Dentistry;1st ed.;New Delhi; Jaypee;2011;26-47.

11. Dabuleanu M. Pulpitis (Reversible/Irreversible). JCDA [serial online]. 2013 August 22;1-4. Available from: $J$ Can Dent Assoc. (http://www.jcda.ca/article/d90).

12. Tarigan R.,Tarigan G. Perawatan Pulpa Gigi (Endodonti); Edisi ketiga; Jakarta; EGC. Th: 23-44.

13. Israel GD. Determining sample size. Program Evalutation and Organization Development; University of Florida; 1992: 6:1-2.

14. Ricucci D., Loghin S., Siqueira J., Correlation Between Clinical and Histologic Pulp Diagnose, Journal of Endodontics.2014; Vol. 40; 1932.

15. Marbun G. Perbedaan Coping Stress pada Pria dan Wanita Dalam Pernikahan: Universitas Sumatra Utara: 2011.

16. Basofi S.Dea. Kenapa Akses Kesehatan Gigi dan Mulut Menjadi Masalah Untuk Perempuan?. (www.rapler.com) diakses tanggal 8 agustus 2017.

17. Lukacs J.,Largaespada L., Explaining sex differences in dental caries prevalence: Saliva,hormones, and "life-history" etiologies, American Journal of Human Biology; 2006.
18. Pedoman Pemeliharaan Kesehatan Gigi dan Mulut Ibu Hamil dan Anak Usia Balita Bagi Tenaga Kesehatan di Fasilitas Pelayanan Kesehatan. Jakarta : Kementerian Kesehatan RI. 2012. 9-1

19. Bender IB. Reversible and Irreversible Painful Pulpitides: Diagnosis and Treatment. Aust Endod J.2000;26(1):10-4.

20. Shaffer John R.,Leslie Elizabeth J.,Feingold Eleanor, et al.Caries Experience Differs between Females and Males across Age Groups in Nothern Appalachia.USA. International Journal of Dentistry.2015.

21. Yazdani S.,Jadidfard M.P.,Tahani B., et al. Health Technology Assessment of CEM Pulpotomy in Permanent Molars with Irreversible Pulpitis. Iranian Endodontic Journal.Iran;2013;23-29.

22. Sagita M.,Cholil,Deby Kania. Gambaran Perawatan Saluran Akar Gigi di Poli Gigi RSUD Ulin Banjarmasin, Jurnal Kedokteran Gigi; Vo.II; 2014.

23. Ahmed H, Durr-e-S, and Munawar R. Frequency and Distribution of Endodontically Treated Teeth. Journal of the College of Physicians and Surgeons Pakistan. 2009;19(10); 605-8.

24. Oglah FS, Baidda MZ and Gholam MK. Evaluation of Endodontic Treatment in Three Specialized Private Clinics in Baghdad (Retrospective Study). Mustansiria Dental Journal. 2011; 8(3); 233-236.

25. Axelsson Per. Diagnosis and Risk Prediction of Dental Caries. London; Quintessence Publishing Co.Inc, 2000. P.23.

26. Marza RSA and Ranj AB. Prevalence and Techinal Quality of Root Canal Treatment in Sulaimani Patients (A Radiographic Evalutation).J Bagh College Dentistry. 2009;21(2); 54

27. Demiburga S, Tuncay O, et al. Frequency and Distribution of Early Tooth Loss and Endodontics Treatments Need of Permanent First Molar in a Turkish Pediatric Population. Eur J Dent. 2013; 7(1): S99-104.

28. Cohen S., Hargreaves K.M. Pathways of the Pulp; $9^{\text {th }}$ ed.; Mosby;USA; 2006. 